\title{
ACUTE TOXICITY AND ENVIRONMENTAL RISK OF DIFLUBENZURON TO Daphnia magna, Poecilia reticulata AND Lemna minor IN THE ABSENCE AND PRESENCE OF SEDIMENT
}

\author{
JAQUELINE PÉROLA DE SOUZA* \\ LOUISE DE SOUZA MEDEIROS** \\ ELISSANDRA ULBRICHT WINKALER*** \\ JOAQUIM GONÇALVES MACHADO-NETO****
}

\begin{abstract}
Parasitoses in fish farming are treated by the application of pesticides formulations commonly used in agriculture or veterinary medicine. For the control of ectoparasites, that cause economic losses to the fish production Diflubenzuron is utilized by direct application into water at a $2 \mathrm{mg} . \mathrm{L}^{-1}$ concentration. However, this practice can intoxicate nontarget species. This research aimed at determining the acute toxicity of diflubenzuron to Daphnia magna, Poecilia reticulata and Lemna minor; evaluating its environmental risk and defining the role of the sediment in the bioavailability of this insecticide in the water. Results of the study implicate diflubenzuron as being extremely toxic to $D$. magna. However, no significant toxicity was observed in $P$. reticulata and $L$. minor. Bioavailability of this insecticide was significantly reduced by the presence of sediment in the water.
\end{abstract}

KEY-WORDS: ECOTOXICITY; ECTOPARASITES; INSECTICIDE; MACROPHYTE; MICROCRUSTACEAN; FISH; DIFLUBENZURON; Daphnia magna; Poecilia reticulate; Lemna minor.

* Bióloga, Mestre em Aquicultura, Doutoranda em Ecologia e Recursos Naturais, Laboratório de Plâncton, Departamento de Hidrobiologia, Universidade Federal de São Carlos (UFSCar), São Carlos, SP (e-mail: souza.jaqueline@gmail.com ).

** Bióloga, Mestre em Aquicultura, Laboratório de Ecotoxicologia e Saúde Ocupacional, Universidade Estadual de São Paulo (UNESP), Jaboticabal, SP (e-mail: louisesouza@yahoo.com.br ).

*** Professor, Centro de Ciências Agrárias, Ambientais e Biológicas, Universidade Federal do Recôncavo da Bahia, Campus Universitário de Cruz das Almas, Cruz das Almas, BA (e-mail: eliswink@hotmail.com ).

**** Professor, Laboratório de Ecotoxicologia e Saúde Ocupacional, Universidade Estadual de São Paulo (UNESP), Jaboticabal, SP (e-mail: joaquim@fcav.unesp.br ). 


\section{INTRODUCTION}

Parasitic infections in fish cause significant economic losses to fish farming. In the absence of products developed specifically for fish, the chemical control of parasite infections has been achieved through applications of pesticides commonly used in agriculture or veterinary medicine (GUIMARÃES, SILVA DE ASSIS \& BOEGER, 2007). Diflubenzuron (DFB) in the formulation Dimilin® is an insecticide registered for agricultural use, but it is also used for the control of ectoparasites in fish ponds at a concentration of $2 \mathrm{mg. \textrm {L } ^ { - 1 }}$ by direct application in water or fish feed (COSTELLO et al., 2001; SCHALCH et al., 2005).

DFB is widely used due to its low toxicity to fish and high efficacy in the control of ectoparasites of the genera Ergasilus sp., Lernaea sp., Dolops sp. and Argulus sp. (SCHOLZ, 1999; DAVIES et al., 2001; COSTELLO et al., 2001; SCHALCH et al., 2005). As a growth regulator, DFB inhibits the synthesis of chitin. Consequently, it impedes ecdysis causing the death of insects and parasites (LEIGHTON, MARKS \& LEIGHTON, 1981). Furthermore, due to its toxicity, DFB can cause intoxication to sensitive non-target aquatic species (GUIMARÃES, SILVA DE ASSIS \& BOEGER, 2007). Additional support is demonstrated by the fact that it is highly toxic to zooplanktonic organisms (NEBEKER et al., 1983; FISHER \& HALL, 1992; SAVITZ et al., 1994). Zooplanktons play important roles in balancing aquatic food chains. These organisms are among producers and secondary consumers; hence any alteration in their populations may lead to an imbalance and possible crash of trophic levels that lie above them (ODUM, BREWER \& BARRETT, 2004). Moreover, applications of DFB in fish farming present intoxication risk to aquatic organisms and must be evaluated before registration and usage permission release.

A sequence of previous studies allows the essential selection of tests for the consideration of toxicity and environmental risk of pesticides (FAO, 1989). The steps of this evaluation process for the registration and eventual usage or application are: standardized laboratory tests, supplementary laboratory studies, simulated field studies and post-registration monitoring. In the first step, tests are conducted to determine chemical and physical properties, besides the compounds primary destiny and acute biological effects in a short-term exposure (FAO, 1989). Furthermore, the process of registration and eventual permission to use a pesticide requires an evaluation of its acute toxicity and environmental risk of pesticides to organisms (STAVOLA \& CRAVEN, 1992). These evaluations are important in the management of toxic substances in aquatic environments; selection and application of control strategies; reduction of probable environmental impacts; and maintenance of physical, chemical and biological integrity of ecosystems (FAO, 1989).

Test results are used to classify pesticides with respect to their acute toxicity and environmental risk. These are based on the mean lethal concentration or mean effective concentration values $\left(\mathrm{LC}_{50}\right.$ or $\mathrm{EC}_{50}$ ) obtained from acute toxicity tests with fish, invertebrates or other suitable aquatic organisms (ZUCKER, 1985). The $\mathrm{LC}_{50}$ values represent the concentration of a substance that results in the death of $50 \%$ of the exposed organisms. On the other hand, $\mathrm{EC}_{50}$ values depict the concentration of a substance that results in a defined effect in $50 \%$ of the total organisms exposed to it (RAND \& PETROCELLI, 1985).

The environmental intoxication risk of those compounds depends directly on their toxicity and susceptibility of the organisms, which relies on the pesticide concentration in the environmental compartment, bioavailability of the pesticide and biology of the organism. When the pesticide is adsorbed by the sediment, the bioavailability in the water for the organisms is normally lower than the initial concentration (FAO, 1989).

The risk of environmental intoxication can be determined by comparing acute toxicity of pesticides to non-target organisms and bioavailability in the environment in terms of use. The organisms selected for this study are internationally recommended for ecotoxicological assessments, and have significant importance in aquatic food chains, facility of handling in the laboratory, and sensitivity to potentially toxic compounds (OECD, 1992; ISO, 1996; OECD, 2002). Therefore, it is important 
in environmental risk assessments to regard different groups of organisms and environmental compartments that can be affected.

The aim of this study was to classify diflubenzuron taking into cognizance its toxicity and possible environmental risk to Daphnia magna, Poecilia reticulata and Lemna minor. In addition, the effect of sediment in bioavailability of the insecticide in the water was also studied.

\section{MATERIALS AND METHODS}

Acute toxicity and sediment effect on the bioavailability of diflubenzuron (DFB) in water were evaluated in bioassays performed at the Ecotoxicology Laboratory of Pesticides and Occupational Health, Universidade Estadual de São Paulo (UNESP), SP-Brazil. The DFB 1-(4-chlorophenyl)-3(2,6-difluoro-benzoyl) urea is known to make up about $25 \%$ in the formulation of the insecticide

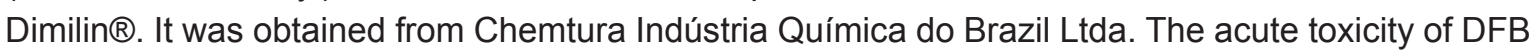
was evaluated through preliminary and definitive tests in accordance to standardized procedures (OECD, 2002; ISO, 1996; OECD, 1992). The tests were performed in the presence and absence of sediment.

\subsection{TEST ORGANISMS}

The neonates of Daphnia magna used on the tests were obtained from cultures of the Ecotoxicology Laboratory of Pesticides and Occupational Health from UNESP. These cultures were kept according to standardized procedures, in distilled water supplemented with nutrients (Basic medium plus M4 medium) at pH $7.0 \pm 0.2$, total hardness (CaCO3) of $250 \pm 25{\mathrm{mg} . \mathrm{L}^{-1}}$ and electrical conductivity of $600 \mu \mathrm{S} . \mathrm{cm}-1$. The cultures were kept in incubator chambers at a temperature of $20 \pm 2^{\circ} \mathrm{C}$, light intensity of 3000 lux and photoperiod of light:dark cycle of 16:8 h. The incubators were kept in an acclimatized room at a temperature of $20 \pm 2^{\circ} \mathrm{C}$. The organisms were fed daily with a ration of Scenedesmus subspicatus $\left(5 \times 106\right.$ cells. day $\left.^{-1}\right)$ and twice a week with fermented solution of ornamental fish food ( $42 \%$ raw protein) and yeast (Saccharomyces cerevisiae). The culture medium was completely renewed twice a week (ISO, 1996).

Mature Poecilia reticulata fishes were obtained from cultures of the Aquaculture Center of UNESP. The organisms were kept for seven days in an acclimatized room in containers of $250 \mathrm{~L}$. The water was constantly renewed from a semi-artesian well and with continuous aeration using electric air pumps. After that, the fish were acclimated in room of tests at a temperature of $24 \pm 2^{\circ} \mathrm{C}$, pH of $7.0 \pm 1$, with 4 mg. $\mathrm{L}^{-1}$ of dissolved oxygen and photoperiod of light:dark cycle of $12: 12 \mathrm{~h}$. The fish were fed once a day with commercial fish food ( $28 \%$ raw protein). Leftover feed and feces were removed from the containers with a siphon every two days.

The macrophytes of the species Lemna minor used in the toxicity tests were obtained from cultures of the UNESP's Ecotoxicology Laboratory of Pesticides and Occupational Health, Brazil, and transferred to glass containers with $1 \mathrm{~L}$ of water enriched with nutrients and with $\mathrm{pH}$ 5.8. The plants were kept in an acclimatized room at $24 \pm 2^{\circ} \mathrm{C}$, light intensity of 6000 lux using white fluorescent bulbs $(20 \mathrm{~W})$ and photoperiod of light:dark cycle of $12: 12 \mathrm{~h}$. Healthy plants with fronds of the similar sizes were chosen for the tests. The culture medium was completely renewed twice a week (OECD, 2002).

Potassium dichromate $\left(\mathrm{K}_{2} \mathrm{Cr}_{2} \mathrm{O}_{7}\right)$ was used as a reference substance for sensitivity evaluation of $D$. magna and $P$. reticulate, and was chosen because it is an environmental contaminant, water soluble, highly toxic in water and legally used as a reference substance in several countries in Europe and America (ENVIRONMENT CANADA, 1990). Sensitivity tests were performed using the same protocol for the acute toxicity essay with DFB. After sixteen sensitivity tests performed with $D$. magna, an average $\mathrm{EC}_{50}$ value of $1.45 \mathrm{mg} . \mathrm{L}-1$ was obtained. This value lies within the permissible range limit for potassium dichromate of 0.9 to $2.0 \mathrm{mg}^{-\mathrm{L}^{-1}}(\mathrm{ISO}, 1996)$. Eight sensitivity tests were 
realized for $P$. reticulata with an average calculated $L_{5}$ value of $74.9 \mathrm{mg} . \mathrm{LL}^{-1}$. It is important to note that LC50 values for $P$. reticulata vary from laboratory to laboratory, hence making it difficult for establish comparison.

Sodium chloride $(\mathrm{NaCl})$ was used as a reference substance for the sensitivity evaluation of $L$. minor. Sodium chloride presented a good concentration to growth inhibition relationship in $L$. minor, therefore served as a good reference substance (BUCKLEY, RUSTAGI \& LAUGHLIN, 1996). Nine sensitivity tests were carried out and the average $\mathrm{EC}_{50}$ value was $4308 \mathrm{mg} . \mathrm{L}^{-1}$. As in the case of $\mathrm{K}_{2} \mathrm{Cr}_{2} \mathrm{O}_{7}$ to $P$. reticulata, L. minor also shows a highly varied toxicity response to $\mathrm{NaCl}$ from laboratory to laboratory.

\subsection{ACUTE TOXICITY}

The preliminary and definitive tests were performed in absence and presence of sediment with the three species under study. Tests in the absence of sediment were performed to evaluate the acute toxicity of DFB, while those in presence of sediment to verify the effect of sediment in the bioavailability of DFB in water. The sediment was collected from the soil surface layer of 0 to $20 \mathrm{~cm}$. The source of the sediment was an area that has been undisturbed for over 20 years and free of toxic residues. The soil was dehydrated, sieved in a $2 \mathrm{~mm}$ sieve and the chemical and granulometric compositions of a $0.5 \mathrm{Kg}$ sample were determined (Table 1). The amount of sediment used at the bottom of the experimental containers was $2 \mathrm{~g}$ for $\mathrm{D}$. magna, $900 \mathrm{~g}$ for $P$. reticulata and $100 \mathrm{~g}$ for $\mathrm{L}$. minor. Water quality parameters like $\mathrm{pH}$, conductivity and dissolved oxygen were measured daily.

The final DFB concentrations used in the study for both experimental types (with or without sediment), were chosen after preliminary tests. These concentrations presented linearity between 0 and $100 \%$ of mortality or toxic effect for the tested species. All tests were performed with three replications per treatment. Controls involved treatments without DFB. The tests were considered valid when the mean toxic effect in the controls did not exceed $20 \%$. After specific exposure time, immobility, mortality or percentage of growth inhibition were determined in the experimental trials. After the determination of $\mathrm{EC}_{50}$ and $\mathrm{LC}_{50}$ values in preliminary tests, the definitive tests were performed $\left(T_{1}, T_{2}\right.$ and $\left.T_{3}\right)$ using the same concentrations and conditions with the goal to get close values of endpoint. Analysis of pesticide concentrations were not performed in acute tests because the degradation time of DFB in water is higher to 9 days at temperatures between 10 and $24^{\circ} \mathrm{C}$ and $\mathrm{pH} 7.7$ (SCHAEFER \& DUPRAS, 1976).

\section{TABLE 1 - CHEMICAL AND GRANULOMETRIC PROPERTIES OF THE SEDIMENT USED IN ACUTE TOXICITY TESTS}

\begin{tabular}{l|r|l|r}
\hline \multicolumn{1}{c|}{ Chemical composition } & Values & Physical composition & Values \\
\hline $\mathrm{pH}\left(\mathrm{CaCl}_{2}\right)$ & 4.7 & Clay $\left(\mathrm{g} \cdot \mathrm{kg}^{-1}\right)$ & 230 \\
$\mathrm{MO} \mathrm{g}^{*}\left(\mathrm{~g}_{\mathrm{dm}} \mathrm{dm}^{3}\right)^{-1}$ & 25.0 & Slime $\left(\mathrm{g} \cdot \mathrm{kg}^{-1}\right)$ & 30 \\
$\mathrm{P}\left(\mathrm{mg}_{\mathrm{dm}}\right)^{-1}$ & 7.0 & Thin sand $\left(\mathrm{g} \cdot \mathrm{kg}^{-1}\right)$ & 340 \\
$\mathrm{~K}\left(\mathrm{mmol}_{\mathrm{c}} \cdot \mathrm{dm}^{3}\right)^{-1}$ & 2.2 & Thick sand $\left(\mathrm{g}^{-1} \mathrm{~kg}^{-1}\right)$ & 400 \\
$\mathrm{Ca}\left(\mathrm{mmol}_{\mathrm{c}} \cdot \mathrm{dm}^{3}\right)^{-1}$ & 12.0 & Texture class & Average \\
$\mathrm{Mg}\left(\mathrm{mmol}_{\mathrm{c}} \cdot \mathrm{dm}^{3}\right)^{-1}$ & 7.0 & & \\
$\mathrm{H}+\mathrm{Al}^{*}\left(\mathrm{mmol}_{\mathrm{c}} \cdot \mathrm{dm}^{3}\right)^{-1}$ & 31.0 & & \\
$\mathrm{SB}\left(\mathrm{mmol}_{\mathrm{c}} \cdot \mathrm{dm}^{3}\right)^{-1}$ & 21.2 & & \\
$\mathrm{~T}^{*}\left(\mathrm{mmol}_{\mathrm{c}} \cdot \mathrm{dm}^{3}\right)^{-1}$ & 52.2 & & \\
$\mathrm{~V}^{*}(\%)$ & 41.0 & & \\
\hline
\end{tabular}

${ }^{*} \mathrm{MO}=$ Organic matter; $\mathrm{H}+\mathrm{Al}=$ Hydrogen + Aluminum; $\mathrm{SB}=$ Sum of the bases; $\mathrm{T}=$ Cations change capacity; $\mathrm{V}=$ Percentage of bases saturation.

Neonates of $D$. magna ( 6 and $24 \mathrm{~h}$ age) were exposed to DFB in glass flasks for $48 \mathrm{~h}$. The 
definitive tests without sediment were performed with concentrations of $0.0001 ; 0.0003 ; 0.0005$; $0.0007 ; 0.0009,0.0011$ and $0.0013 \mathrm{mg} . \mathrm{L}^{-1} ;$; wile in the definitive tests with sediment the concentrations

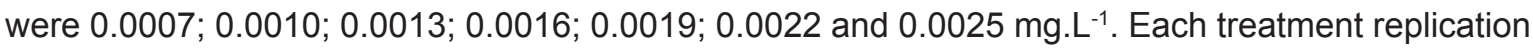
was made up of $10 \mathrm{~mL}$ of the test solution containing 5 neonates. After each exposure period, immobility of organisms in each experimental trial was determined (ISO, 1996).

Mature males weighing $0.12 \pm 0.08 \mathrm{~g}$ were exposed to DFB in glass flasks for $96 \mathrm{~h}$. Definitive tests in the absence of sediment were performed with the concentrations of $70 ; 100 ; 130 ; 160 ; 190$; 210 and 240 mg. L-1 and those with sediment the concentrations were 155; 190; 225; 260; 295; 330 and $365 \mathrm{mg} \cdot \mathrm{L}^{-1}$. Five animals were exposed at a final volume of $3000 \mathrm{~mL}$ test solution per replication. After every $24 \mathrm{~h}$, the number of animals was counted and the dead ones were taken out of each experimental set up (OECD, 1992).

L. minor plants were exposed to DFB for seven days. The definitive tests without sediment

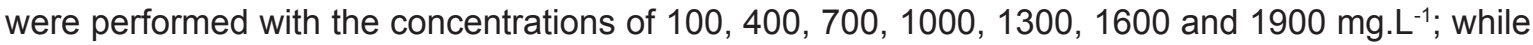

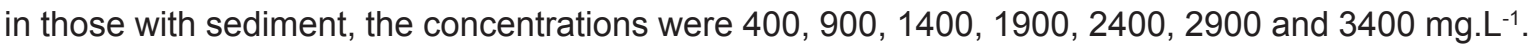
Four plants were exposed summing up to give 12 fronds at a final volume of $100 \mathrm{~mL}$ test solution. After the exposure period, the number of fronds in each experimental trial was counted and the percentage growth inhibition calculated (OECD, 2002).

\subsection{ACUTE TOXICITY AND ENVIRONMENTAL RISK CLASSIFICATION}

The acute toxicity and environmental classification were based on guidelines of the Hazard Evaluation Division of USEPA (ZUCKER, 1985; URBAN \& COOK, 1986). Diflubenzuron has been classified for acute toxicity based on the values of EC50 and LC50 estimated in tests with different aquatic organisms. The classes of acute toxicity were: extremely toxic (LC50 or EC50 < $0.1 \mathrm{mg} . \mathrm{L}-1$ ), highly toxic $\left(0.1<\mathrm{LC}_{50}\right.$ or $\left.\mathrm{EC}_{50}<1.0 \mathrm{mg} . \mathrm{L}-1\right)$, moderately toxic $(1.0<\mathrm{LC} 50$ or EC50 $<10.0 \mathrm{mg.L}-1)$, slightly toxic $\left(10.0<\mathrm{LC}_{50}\right.$ or $\left.\mathrm{EC}_{50}<100.0 \mathrm{mg} \cdot \mathrm{L}^{-1}\right)$, and practically non-toxic $\left(\mathrm{LC}_{50}\right.$ or $\mathrm{EC}_{50}>100.0$ $\left.\mathrm{mg} \cdot \mathrm{L}^{-1}\right)$.

The DFB was also classified by environmental risks using the recommended concentration of the product through the quotient method (Q) described by Urban \& Cook (1986). The $Q$ value was calculated by dividing the Estimated Environmental Concentration (EEC) $2{\mathrm{mg} . \mathrm{L}^{-1}}$ by $\mathrm{LC}_{50}$ or $\mathrm{EC}_{50}$ determined in acute toxicity tests. The EEC is the concentration used normally in fish farms for control of ectoparasites (COSTELLO et al., 2001; SCHALCH et al., 2005). The environmental risk classes were as follows: risk without adverse effect $(Q \leq 0.1)$, risk with moderate adverse effect $(0.1 \leq Q \leq 10)$ and risk with high adverse effect $(Q>10)$.

\subsection{STATISTICAL ANALYSES}

The values of $\mathrm{EC}_{50}$ and $\mathrm{LC}_{50}$ of definitive tests were determined using the Trimmed SpermanKarber (HAMILTON, RUSSO \& TUSRTUN, 1977) statistical analysis program. Data obtained from the different experimental setups were analyzed in two-way ANOVA with replications. Significantly different means were separated by Tukey test at $5 \%$ significance level. The SAS software for windows was used for all other data analysis (SAS, 1999).

\section{RESULTS AND DISCUSSION}

The $\mathrm{EC}_{50}$ and $\mathrm{LC}_{50}$ values obtained from the three definitive tests $\left(\mathrm{T}_{1}, \mathrm{~T}_{2}\right.$ and $\left.\mathrm{T}_{3}\right)$, in presence and absence of sediment, are shown in Table 2 and in the Figures 1, 2 and 3. Daphnia magna was the most sensitive to DFB. The insecticide had adverse effects on the cladoceran at low concentrations, in the absence or presence of sediment. The insecticide is very toxic to zooplankton. Nebeker, Mckinney \& Cairns (1983) determined that the $48 \mathrm{~h}-\mathrm{EC}_{50}$ of DFB to $D$. magna was $0.002 \mathrm{mg} \cdot \mathrm{L}^{-1}$. The cladocerans 
Bosmina longirostris, Ceriodaphnia $s p$. and Daphnia laevis were eliminated after exposure to DFB at $0.012 \mathrm{mg} \cdot \mathrm{L}^{-1}$ in water (FISHER \& HALL, 1992). The concentration of $0.0022 \mathrm{mg} \cdot \mathrm{L}^{-1}$ of DFB in water reduced $50 \%$ of nauplii population of the estuarine copepode Eurytemora affinis; while sub lethal concentration of $0.00078 \mathrm{mg} \cdot \mathrm{L}^{-1}$ affected the survival and development of nauplii five days after exposure (SAVITZ, DAVID \& SMUCKER, 1994). In this study, the acute toxicity of DFB was more elevated for D. magna (Tables 2 and 3 ) than that reported for other zooplankton in literature. This outcome indicates that the sensitivity of these organisms to DFB may be changing over time or that the strain of D. magna is more sensitive. This is because lower concentrations of DFB were toxic to this organism. In agreement with results from other studies, it is easy to concur that low concentrations of DFB can eliminate sensitive zooplanktonics organisms. Toxic effects of diflubenzuron were observed in other groups of organisms. Honey bees (Apis mellifera) had difficulty performing learned tasks when exposed to diflubenzuron (ABRAMSON et al., 2004). Juvenile of blue crabs (Callínectes sapidus) also were damaged in relation to the age and molt-stage with the exposure to diflubenzuron (REBACH \& FRENCH, 1996). The results of this study indicate that the presence of DFB in the aquatic environments can affect the survival of zooplankton, thereby disrupting the food chain balance. The decrease in the survival of zooplankton can be a threat to the fish that feed on them.

TABLE 2 - THE EC ${ }_{50}$ AND LC $_{50}$ VALUES (mg.L-1) OF DIFLUBENZURON DETERMINED FOR THE THREE AQUATIC ORGANISMS, IN THE PRESENCE AND ABSENCE OF SEDIMENT, IN THE THREE DEFINITIVE TESTS $\left(T_{1}, T_{2}\right.$ AND $\left.T_{3}\right)$, MEANS \pm STANDARD DEVIATION

\begin{tabular}{|c|c|c|c|c|}
\hline \multirow{2}{*}{ Species } & \multicolumn{3}{|c|}{$\mathrm{EC}_{50}$ or $\mathrm{LC}_{50}\left(\mathrm{mg} \cdot \mathrm{L}^{-1}\right)$ Without Sediment } & \multirow{2}{*}{ Mean \pm SD* $^{*}$} \\
\hline & $\mathrm{T}_{1}$ & $\mathrm{~T}_{2}$ & $\mathbf{T}_{3}$ & \\
\hline D. magna & 0.00036 & 0.00056 & 0.00076 & $0.00056 \mathrm{~b} \pm 0.00020$ \\
\hline P. reticulata & 145.54 & 159.31 & 151.09 & $151.98 b \pm 6.93$ \\
\hline \multirow[t]{3}{*}{ L. minor } & 373.33 & 534.61 & 470.52 & $459.50 \mathrm{~b} \pm 81.20$ \\
\hline & \multicolumn{3}{|c|}{$\mathrm{EC}_{50}$ or $\mathrm{LC}_{50}\left(\mathrm{mg} \cdot \mathrm{L}^{-1}\right)$ With Sediment } & \multirow[t]{2}{*}{ Mean \pm SD* $^{*}$} \\
\hline & $\mathrm{T}_{1}$ & $\mathrm{~T}_{2}$ & $\mathrm{~T}_{3}$ & \\
\hline \multirow{2}{*}{$\begin{array}{l}\text { D. magna } \\
\text { P. reticulata }\end{array}$} & 0.00159 & 0.00157 & 0.00138 & $0.00151 \mathrm{a} \pm 0.00011$ \\
\hline & 303.38 & 245.41 & 284.70 & $277.83 \mathrm{a} \pm 29.59$ \\
\hline L. minor & 600.00 & 796.50 & 698.25 & $698.25 a \pm 98.25$ \\
\hline
\end{tabular}

* $\mathrm{SD}=$ standard deviation. Means with different alphabets along the columns differ statistically (Tukey's test, $p<0.05$ ). $\mathrm{T}_{1}, \mathrm{~T}_{2}$ and $\mathrm{T}_{3}$ means definitive test 1,2 and 3 .

In this study the significant toxicity was exhibited by DFB to $D$. magna. In contrast to what was observed with $D$. magna, the other test organisms were less sensitive to the DFB, thereby showing no significant toxic effect. Diflubenzuron was slightly toxic to the fish Poecilia reticulata (Table 2; Figure 2). It also has low toxicity to other species of fish. The $96 \mathrm{~h}-\mathrm{LC}_{50}$ of DFB to Oncorhynchus mykiss

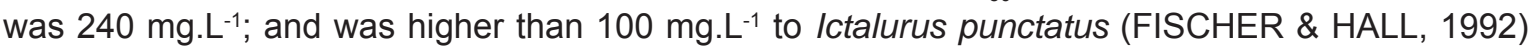
and Lepomis macrochirus (PATTERSON, 2004). For Salvelinas fontinalis and Perca flavescens, the $96 \mathrm{~h}-\mathrm{LC}_{50}$ was higher than $50 \mathrm{mg} . \mathrm{L}^{-1}$ and $25 \mathrm{mg}^{\mathrm{L}} \mathrm{L}^{-1}$, respectively (PATTERSON, 2004). Although, acute toxicity occurs at high concentrations of DFB for fish, sub lethal toxic effects may occur in low concentrations of the product. Patterson (2004) found out that the exposure to concentrations greater than $0.10 \mathrm{mg} \cdot \mathrm{L}^{-1}$ of DFB affected the life cycle of Pimephales promelas. The species Prochilodus lineatus, exposed for 6, 24 and 96 hours to $25 \mathrm{mg} . \mathrm{L}-1$ had a reduction in number of erythrocytes and in the content of hemoglobin and hyperglycemia; an induction of glutathione-S-transferase (GST) and catalyses enzymes activities; decreased muscular acetylcholinesterase and hepatics alterations (MADUENHO \& MARTINEZ, 2008). 


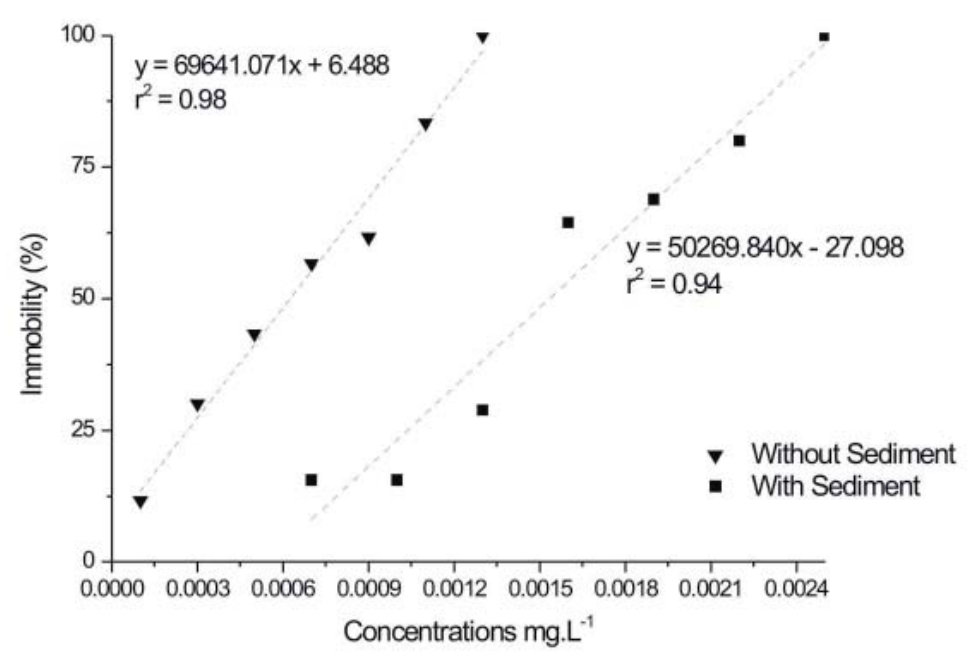

\section{FIGURE 1 - CONCENTRATIONS OF DFB AND THE PERCENTAGE OF IMMOBILITY IN THE ABSENCE AND PRESENCE OF SEDIMENT TO Daphnia magna}

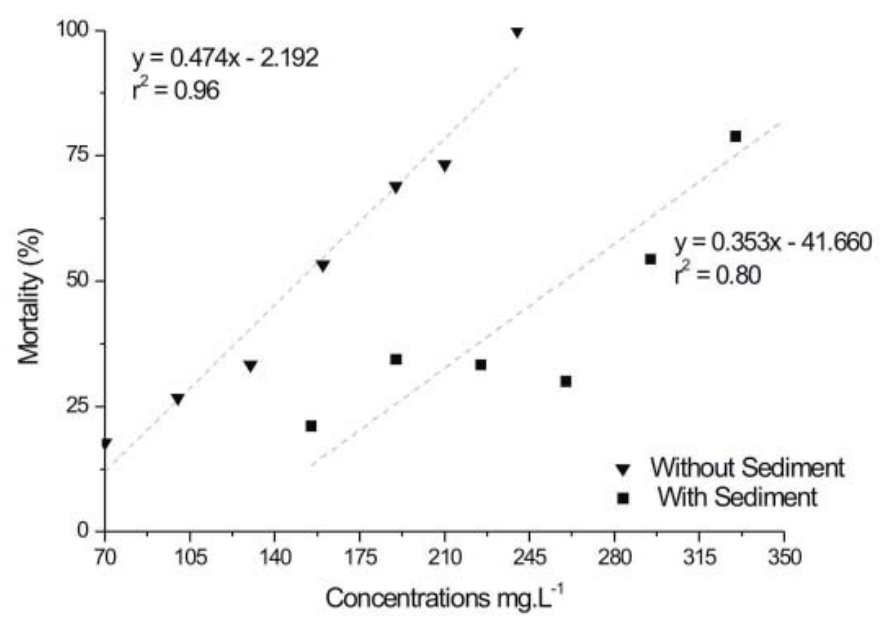

\section{FIGURE 2 - CONCENTRATIONS OF DFB AND THE PERCENTAGE OF MORTALITY IN THE ABSENCE AND PRESENCE OF SEDIMENT TO Poecilia reticulata}

The insecticide also showed slight toxicity to the macrophyte L. minor (Figure 3). This effect was expected because DFB has a regulatory action in the synthesis of chitin in arthropods, a biochemical mechanism absent in plants. Consequently, the plants are more tolerant to these kinds of contaminants. In line with this, aquatic macrophytes and algae are known to be resistant to DFB (EISLER, 2000). However, DFB can affect the rate of photosynthesis in macrophytes and algae. Experiments conducted in this study demonstrated that concentrations exceeding $700 \mathrm{mg} \cdot \mathrm{L}^{-1}$ caused a whitish appearance of the fronds of the macrophyte. This implicated DFB as the possible interferential agent that decrease the frond chlorophyll content. Skeletonema costatum has shown

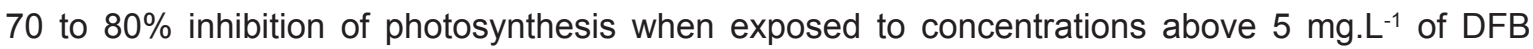
(EISLER, 2000). In contrast, it is postulated that the effects of insecticides on aquatic macrophytes plants can also occur in an indirect way in the natural environment. The presence of insecticide 
causes zooplankton mortality, which in turn reduces the foraging pressure on algae. This encourages the excessive proliferation of phytoplankton, which competes with the macrophytes for light, space and nutrients (WENDT-RASCH et al., 2004). Studies on the acute toxicity of DFB to aquatic plants were not find in the literature. In this study, macrophytes and fish did not suffer acute lethal effects when exposed to high concentrations of the DFB. However, a chronic exposure to low concentrations may cause toxicity to these aquatic organisms.

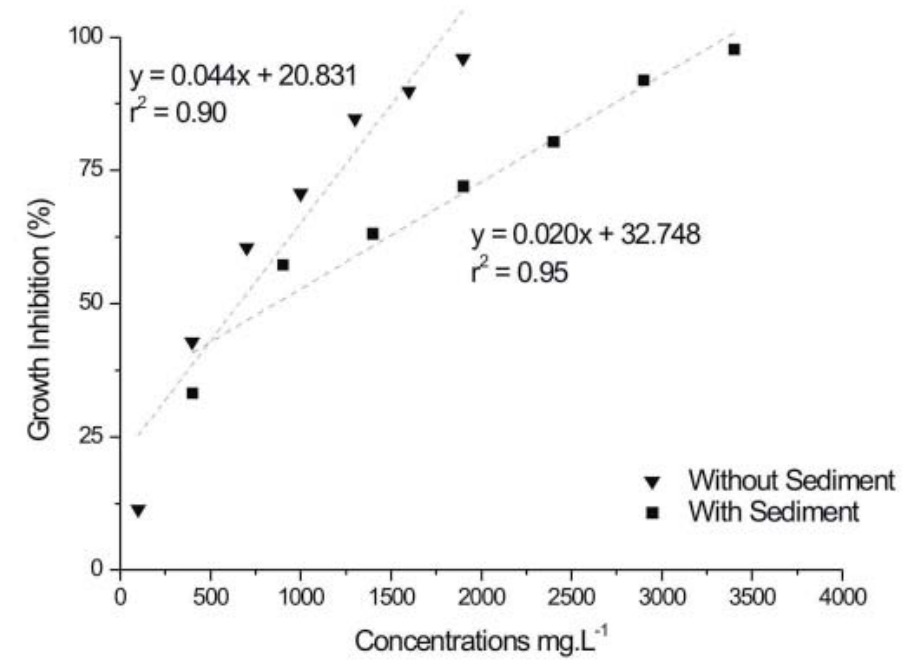

\section{FIGURE 3 - CONCENTRATIONS OF DFB AND THE PERCENTAGE OF GROWTH INHIBITION IN THE ABSENCE AND PRESENCE OF SEDIMENT TO Lemna minor}

The adsorption of DFB to sediment decreased its bioavailability in the water and significantly reduced $(p<0.05)$ the toxicity to the three species studied (Table 2$)$. The DFB toxicity was 2.7 times lower for the cladoceran (D. magna), 1.83 times lower for the fish (P. reticulata) and 1.52 times lower for the macrophyte (L. minor) in the presence of sediment. These results indicate the important role of the sediment in the regulation of toxicity of toxic agents in the water. In the presence of sediment, the values of $\mathrm{EC}_{50}$ and $\mathrm{LC}_{50}$ were significantly higher, i.e., higher concentrations of DFB were required to cause the same effect on the test organism as those in the absence of sediment. In another study, the presence of sediment reduced the bioavailability of herbicides, atrazine and molinate, in water to Daphnia carinata. The $48 \mathrm{~h}-\mathrm{EC}_{50}$ of atrazine increased from 24.6 to $30.7 \mathrm{mg} \cdot \mathrm{L}^{-1}$ and that of molinate from 26.6 to $46.4 \mathrm{mg} \cdot \mathrm{L}^{-1}$ (PHYU, WARNE \& LIM, 2004). The reduction of bioavailability of atrazine and molinate was attributed to the organic matter content in the sediment. As in the case of atrazine and molinate, the reduction of bioavailability of DFB in water can also be attributed to the organic matter content present in the sediment. The non ionic and hydrophobic properties of DFB are responsible for its fast adsorption to organic matter. The toxicity of the non ionic complex is affected by the organic matter content of sediment (CARRINGER, WEBER \& MÔNACO, 1975). Probably, the static system of experiments helped in reducing the availability of the DFB in water. During the course of the experiment, over the time, much of DFB was adsorbed by the sediment, consequently, reducing the toxicity to aquatic organisms. The acute intoxication of the organic-synthetic insecticide DDT to Hyalella azteca decreased with the increasing of concentration of total organic carbon in the sediment (NEBEKER et al., 1989). Furthermore, the adsorption of pesticides in sediment can harm benthic species. The exposure to concentrations from 0.007 to $0.030 \mathrm{mg}^{-L^{-1}}$ of DFB caused pronounced changes in the coastal benthic macroinvertebrate community structure of the chironomidae and ephemeroptera groups 
(O'HALLORAN et al., 1996). These community structure alterations were persistent for a period of 57 days. Although, the adsorption of DFB to sediment decreases its bioavailability to the organisms that inhabit the water column, it may increase its toxicity to benthic organisms.

In accordance with the $48 \mathrm{~h}-\mathrm{EC}_{50}$ values obtained for $D$. magna in absence and presence of sediment (Table 2), DFB is classified as extremely toxic (Table 3), based on the acute toxicity classes described by the Hazard Evaluation Division, USEPA Publication (ZUCKER, 1985). On the other hand, the $96 \mathrm{~h}-\mathrm{LC}_{50}$ and 7 days $-\mathrm{EC}_{50}$ values determined for $P$. reticulata and $L$. minor respectively, with and without sediment (Table 2), classified the DFB as practically non-toxic (Table 3). Based on the 48 $\mathrm{h}-\mathrm{EC}_{50}$ values determined for $D$. magna in the absence and presence of sediment (Table 2) and in EEC (Estimated Environmental Concentration), the DFB is classified as high adverse effect risk in the environment (Table 3). The very high $Q$ values obtained are in agreement with this determination. The values of $96 \mathrm{~h}-\mathrm{LC}_{50}$ and 7 days-EC $\mathrm{E}_{50}$ determined for $P$. reticulata and L. minor respectively, in the presence and absence of sediment (Table 2), and the EEC, influenced the classification of DFB as without adverse effect risk to the environment (Table 3) (URBAN \& COOK, 1986). These results indicated that the insecticide DFB is potentially toxic to the cladoceran and less toxic to fish and macrophyte. Environmental risk assessment is important in the protection of populations, communities and ecosystems (SOLOMON, 1996). In aquaculture, chemical products are used in water or rations for treatment and prevention of cultivated organisms from diseases (COSTELLO et al., 2001). In accordance with the results of this study on $D$. magna, this insecticide is classified as being extremely toxic (Table 3 ) and of high adverse effect to the environment. Therefore, the concentration of DFB used in aquaculture is toxic to this zooplankton. This organism is directly linked to other organisms in aquatic food chains, especially between producers and costumers. Hence, any change in zooplankton populations can adversely affect other trophic levels (MANGAS-RAMÍREZ, SARMA \& NANDINI, 2001)

\section{TABLE 3 - CLASSIFICATION OF DFB ACCORDING TO ACUTE TOXICITY AND ENVIRONMENTAL RISK BASED ON THE CRITERIA OF ZUCKER (1985) AND URBAN AND COOK (1986)}

\begin{tabular}{l|c|r|r|c}
\hline \multirow{2}{*}{ Species } & \multirow{2}{*}{ Acute toxicity } & \multicolumn{2}{|c|}{ Q } & \multirow{2}{*}{ Environmental risk } \\
\cline { 3 - 4 } & & Without sed. & \multicolumn{1}{c}{ With sed. } & \\
\hline D. magna & Extremely toxic & 3571.4200 & 1324.5033 & Great adverse effect \\
P. reticulata & Non-toxic & 0.0132 & 0.0072 & No effect \\
L. minor & Non-toxic & 0.0044 & 0.0029 & No effect \\
\hline
\end{tabular}

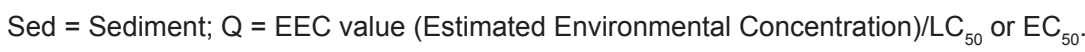

\section{CONCLUSION}

In conclusion, the DFB concentration used in aquaculture is very toxic to $D$. magna and less toxic to $P$. reticulata and $L$. minor. This means that the concentration used in treatment of parasites of fish may eliminate other related planktonic organisms. Thus, the use of this product in aquaculture should be limited to restrict environments, to minimize possible negative impacts on aquatic food chains. The presence of sediment decreases the bioavailability of DFB in water and reduces the intoxication of species that live in the water column. Bioavailability of DFB in the water column with reference to the presence or absence of sediment should be considered in toxicity tests. Recommendations are made that further studies be carried out to determine the acute and chronic toxic effects of DFB to aquatic plants. This information will broaden the depth of the understanding of the mechanisms of action, transformations and dynamics of this insecticide in plants in the water column. 


\section{RESUMO}

TOXICIDADE AGUDA E RISCO AMBIENTAL DO DIFLUBENZURON PARA Daphnia magna, Poecilia reticulata E Lemna minor NA AUSÊNCIA E PRESENÇA DE SEDIMENTO

Parasitoses em pisciculturas são tratadas com a aplicação de formulações de pesticidas comumente usadas na agricultura ou na veterinária. O diflubenzuron, empregado no controle de ectoparasitas que causam perdas econômicas na produção de peixes, é aplicado diretamente na água na concentração de $2 \mathrm{mg}^{\mathrm{L}} \mathrm{L}^{-1}$. Entretanto, essa aplicação pode intoxicar espécies não alvo. Este trabalho objetivou determinar a toxicidade aguda do diflubenzuron para Daphnia magna, Poecilia reticulata e Lemna minor; avaliar seu risco ambiental e definir o papel que o sedimento desempenha na biodisponibilidade desse inseticida na água. Os resultados deste estudo mostraram que o diflubenzuron é extremamente tóxico para $D$. magna. Entretanto, não foi observada toxicidade significativa para $P$. reticulata e $L$. minor. A biodisponibilidade desse inseticida foi significativamente reduzida pela presença do sedimento na água.

PALAVRAS-CHAVE: ECOTOXICIDADE; ECTOPARASITOSES; PEIXES; INSETICIDA; MACRÓFITAS; MICROCRUSTÁCEOS; Daphnia magna; Poecilia reticulata; Lemna minor.

\section{REFERENCES}

1 ABRAMSON, C. I.; SQUIRE, J.; SHERIDAN, A.; MULDER Jr, P. G. The effect of insecticides considered harmless to honey bees (Apis mellifera L.): Proboscis conditioning studies using the insect growth regulators Confirm $^{\circledR} 2 \mathrm{~F}$ (Tebufenozide) and Dimilin ${ }^{\circledR} 2$ L (Diflubenzuron). Environmental Entomology, v. 33, p. 378-388, 2004.

2 BUCKLEY, J. A.; RUSTAGI, K. P.; LAUGHLIN, J. D. Response of Lemna minor to sodium chloride and a statistical analysis of continuous measurements for $\mathrm{EC}_{50}$ and $95 \%$ confidence limits calculation. Bulletin of Environmental Contamination and Toxicology, v. 57, p. 1003-1008, 1996.

3 CARRINGER, R. D.; WEBER, J. B.; MÔNACO, T. Adsorption-desorption of selected pesticides by organic matter and montmorillonite. Journal of Agricultural and Food Chemistry, v. 23, p. 568-572, 1975.

4 COSTEllo, M. J.; GRANT, A.; DAVIES, I. M.; CECCHINI, S.; PAPOUTSOGLOU, S.; QUIGLY, D.; SAROGLIA, M. The control of chemicals used in Europe. Journal of Applied Ichthyology, v. 17, p. 173180, 2001.

5 DAVIES, I. M.; RODGER, G. K.; REDSHAW, J.; STAGG, R. M. Targeted environmental monitoring for the effects of medicines used to treat sea-lice infestation on farmed fish. ICES Journal of Marine Science, $v$. 58, p. 477-485, 2001.

6 EISLER, R. Handbook of chemical risk assessment: health hazards to humans, plants, and animals. Maryland, USA: Potomac, 2000. 4141 p. v.1.

7 ENVIRONMENT CANADA. Report EPS 1/RM/12: guidance document on control of toxicity test precision using reference toxicants. Ottawa, Ontario, 1990. $85 \mathrm{p}$.

8 FAO. Food and Agriculture Organization of the United Nations. Revised guidelines on environmental criteria for the registration of pesticides. Rome, 1989. $51 \mathrm{p}$.

9 FISCHER, S. A.; HALL, L. W. Environmental concentrations and aquatic toxicity data on diflubenzuron (Dimilin). Critical Review in Toxicology, v. 22, p. 45-79, 1992.

10 GUIMARÃES, A. T. B.; SILVA de ASSIS, H. C.; BOEGER, W. The effects of trichorfon on acetylcholinesterase activity and histhopathology of cultivated fish Oreochromis niloticus. Ecotoxicology and Environmental Safe, v. 68, p. 57-62, 2007.

11 HAMILTON, M. A.; RUSSO, R. C.; TUSRTUN, R. V. Trimmed Spearman-Karber method for estimating median lethal concentrations in toxicity bioassays. Environmental Science Technology, v. 11, p. 714-719, 1977.

12 ISO. International Organization for Standardization. ISO 6341: water quality determination of the mobility of Daphnia magna Straus (Cladocera, Crustacea). Geneve, 1996. 12 p. 
13 LEIGHTON, T.; MARKS, E.; LEIGHTON, F. Pesticides: insecticides and fungicides and chitin synthesis inhibitors. Science, v. 213, p. 905-907, 1981.

14 MADUENHO, L. P.; MARTINEZ, C. B. R. Acute effects of diflubenzuron on the freshwater fish Prochilodus lineatus. Comparative Biochemistry and Physiology Part C, Pharmacology, Toxicology and Endocrinology, v. 148, p. 265-272, 2008.

15 MANGAS-RAMÍREZ, E.; SARMA, S. S. S.; NANDINI, S. Toxicity of ammonium chloride to the cladoceran Daphnia pulex Leygig in relation to algal food density. Bulletin of Environmental Contamination and Toxicology, v. 67, p. 834-840, 2001.

16 NEBEKER, A. V.; MCKINNEY, P.; CAIRNS, M. A. Acute and chronic effects of diflubenzuron (Dimilin) on freshwater fish and invertebrates. Environmental Toxicology and Chemistry, v. 2, p. 329-336, 1983.

17 NEBEKER, A. V.; SCHUYTEMA, G. S.; GRIFFIS, W. L.; BARBITTA, J. A.; CAREY, L. A. Effect of sediment organic carbon on survival of Hyalella azteca exposed to DDT and eldrin. Environmental Toxicology and Chemistry, v. 8, p. 705-718, 1989.

18 ODUM, E.; BREWER, R.; BARRETT, G. W. Fundamentals of ecology. Belmont, CA: Brooks Cole, 2004. $624 \mathrm{p}$.

19 OECD. Organization for Economic Cooperation and Development. Fish, acute toxicity test. In: GUIDELINE for testing of chemicals. Paris, 1992. 9 p. v. 2003

20 OECD. Organization for Economic Cooperation and Development. Lemna sp. growth inhibition test. In: GUIDELINE for testing of chemicals. Paris, 2002. 22 p.

21 O'HALLORAN, S. L.; LIBER, K.; SCHMUDE, K. L.; CORRY, T. D. Effects of diflubenzuron on benthic macroinvertebrates in littoral enclosures. Archives of Environmental Contamination and Toxicology, $v$. 30, p. 444-451, 1996.

22 PATTERSON, M. Diflubenzuron: analysis of risks to endangered and threatened salmon and steelhead. Washington: Environmental Protection Agency Policy and Regulatory Services Branch and Environmental Field Branch Office of Pesticide Programs, 2004. 93 p.

23 PHYU, Y. L.; WARNE, M. St. J.; LIM, R. P. Toxicity of atrazine and molinate to the cladoceran Daphnia carinata and the effect of river water and bottom sediment on their bioavailability. Archives of Environmental Contamination and Toxicology, v. 46, p. 308-315, 2004.

24 RAND, G. M.; PETROCELLI, S. R. Fundamentals of aquatic toxicology. Washington: Hemisphere Publishing Corporation, 1985. $666 \mathrm{p}$

25 REBACH, S.; FRENCH, D. Effects of dimilin on the blue crab, Callínectes sapidus, in shallow-water habitats. Estuaries, v. 19, p. 279-287, 1996

26 SAS Institute. Users guide: statistics. Cary, 1999.

27 SAVITZ, J. D.; DAVID, A.; SMUCKER, R. A. Toxic effects of the insecticide diflubenzuron (dimilin ${ }^{\circledR}$ ) on survival and development of nauplii of the estuarine copepod Eurytemora affinis. Marine Environmental Research, v. 37 , p. $297-312,1994$

28 SCHAEFER, C.; DUPRAS, E. F. Jr. Factors affecting the stability of dimilin in water and the persistence of dimilin in fild wasters. Journal of Agricultural and Food Chemistry, v. 24, p. 733-739, 1976.

29 SCHALCH, S. H. C.; BELO, M. A. A.; SOARES, V. E.; MORAES, J. R. E.; MORAES, F. R. Diflubenzuron effectiveness in Dolops carvalhoi (Crustacea: Branchiura) control in juvenile pacus Piaractus mesopotamicus (Osteichthyes: Characidae) naturally infected. Acta Scientarium, Animal Science, v. 27, p. 297-302, 2005.

30 SOLOMON, K. R. Overview of recent developments in ecotoxicological risk assessment. Risk Analysis, v.16, p. 627-633, 1996.

31 SCHOLZ, T. Parasites in cultured and feral fish. Veterinary Parasitology, v. 84, p. 317-335, 1999. 
32 STAVOLA, A. M.; CRAVEN, H. Terrestrial ecological risk assessment of pesticides in the United States. In: GREIG-SMITH, P. W.; BECKER, H.; EDWARDS, P. J.; HEIMBACH, F. Ecotoxicology of earthworms. London: Intercept, 1992. p. 177-184.

33 URBAN, D. J.; COOK, N. J. Standard evaluation procedure ecological risk assessment. Washington: Hazard Evaluation Division of USEPA, 1986. (Publication 540/9-86-001).

34 WENDT-RASCH, L.; VAN DEN BRINK, P. J.; CRUM, S. J. H.; WOIN, P. The effects of pesticide mixture on aquatic ecosystems differing in trophic status: responses of the macrophyte Myriophyllum spicatum and the periphytic community. Ecotoxicology and Environmental Safe, v. 57, p. 383-398, 2004.

35 ZUCKER, E. Standard evaluation procedure acute toxicity test for freshwater fish. Washington: Hazard Evaluation Division of USEPA, 1985. (Publication 540/9-85-006). 